there followed no less than four more editions.

The influence of Nazi ideology on every phase of intellectual life in totalitarian Germany is excellently illustrated by this book in the seemingly neutral field of book lore. For its postwar appearance the book may have undergone certain revisions of its wartime text. Regardless of whether or not this was the case, its basic outlook has not changed; its spirit is still the same.-Hellmut Lehmann-Haupt, New School for Social Research.

\section{Eugene Stollreither}

Festschrift Eugen Stollreither zum 75. Geburtstage gewidmet von Fachgesen, Schuelern, Freunden. Herausgegeben von Fritz Redenbacher. Mit 34 Tafeln. Erlangen, Universitaetsbibliothek, 1950. xii, 403p., $32 \mathrm{pl}$. DM 44-.

This impressive volume represents primarily South-German scholarship, edited by the present director of the University Library of Erlangen in honor of his predecessor. Most of the 35 contributions deal with historical problems about books, printing, binding and illustrations; they are in many cases well and amply illustrated. The editor himself contributes one of the most interesting of these studies, dealing with the shifts in interpreting the meaning of renaissance book illustration.

Eight of the papers are of more than passing concern to librarians. Three of these deal with three outstanding men: Friedrich Kraftdiscusser Achille Ratti, later Pope Pius XI; Georg Leyh adds significant information about August Wilmanns (Preussische Staatsbibliothek); Henri F. Raux gives highlights of the career of the French protagonist of public libraries, Eugène Morel.

Five papers deal with various aspects of library administration. Friedrich Bock treats of medieval manuscript catalogs as forerunners of the alphabetical subject catalog (= dictionary catalog); Agnes Staehlin of some problems involved in making such catalogs today. Gustav Hofmann analyzes the personnel problem in German scholarly libraries; Schnorr von Carolsfeld characterizes a typical scholar-librarian, drawing on his intimate association with an outstanding example, his father, who was a predecessor of
Gustav Hofmann as the Chief Director of the Bavarian State Library and its function in the U.S.A.

Anyone interested in the tradition of the book will want to glance through this fine treatise, read some of it, enjoy the illustrations and make notes for future reference.Icko Iben, Champaign, Illinois.

\section{Key Literature}

Die Schlüsselliteratur. By Georg Schneider. Stuttgart, Hiersemann, 1951-52. 2 vols. DM 32.00.

The distinguished author of the Handbuch der Bibliographie has labored for twenty-five years on another monumental work which will be an essential title in every reference collection. Schlüsselliteratur, rather awkwardly translated into English as "key literature," refers to books which portray real persons and events under the guise of fictitious names. The genre poses rather difficult problems for beginning students of literary history; but, strangely enough, the only study prior to Schneider's is A. Ferdinand Drujon's Livres à clef (1888), which deals with French erotic and satirical literature of the seventeenth and eighteenth centuries.

The first volume ("Das literarische Besamtbild") contains definitions, history and criticism, with indexes of authors and prototypes. The second volume ("Entschlüsselung deutscher Romane und Dramen") contains a detailed account of all more important German fiction and drama which deal with reality in the guise of imaginative writing. Each title is analyzed in detail with references to pertinent critical literature. The third volume, not yet published, will deal with non-German "key literature," particularly in English, French, and the Scandinavian languages.

The earliest examples of "key literature" may be found in the fifteenth century with such works as Sannazaro's pastoral romance, Arcadia, and Emperor Maximilian's Theuerdank; but the genre's possibilities were not fully recognized before the baroque period. Throughout the periods of classicism and romanticism in Europe the roman à clef enjoyed unusual popularity mainly for reasons of courtesy and respect for the feelings of others. Perhaps the most famous example of all is 